\title{
INVESTIGATION OF PROCESS STABILITY AND WELD QUALITY OF UNDERWATER WET FLUX-CORED ARC WELDING OF LOW-ALLOY HIGH-STRENGTH STEEL WITH OXY-RUTILE WIRE
}

\author{
Hongliang $\mathrm{Li}^{* 1,2}$ \\ Shixiong Liu ${ }^{1}$ \\ Qiang $\mathrm{Ma}^{1}$ \\ Pengfei Wang ${ }^{3}$ \\ Duo Liu ${ }^{2}$ \\ Qiang Zhu ${ }^{1}$ \\ ${ }^{1}$ School of Materials Science\&Engineering, Jiangsu University, Zhenjiang, China \\ ${ }^{2}$ State Key Laboratory of Advanced Welding and Joining, Harbin Institute of Technology, Harbin, China \\ ${ }^{3}$ Institute of Mechanical Engineering, Materials and Transport, Peter the Great St. Petersburg Polytechnic University, St. Petersburg, Russia \\ *Corresponding author: lihongliang23@163.com (H. Li)
}

\begin{abstract}
The paper described the experimental findings of underwater wet welding of E40 steel using self-shielded flux-cored wire with a $\mathrm{TiO}_{2}-\mathrm{FeO}-\mathrm{MnO}$ slag system. The arc stability, weld quality and corrosion resistance with different heat inputs were studied. The results showed that the wet welding process of the designed wire displayed good operability in the range of investigated parameters. The microstructure and mechanical properties of the weld metal depended on the heat input. Due to the high fraction of acicular ferrite in the weld metal, the mechanical properties of the weld metal under low heat input had better tensile strength and impact toughness. Fracture morphologies at low heat input had uniform and small dimples, which exhibited a ductile characteristic. The diffusible hydrogen content in the deposited metal obtained at a heat input of $26 \mathrm{~kJ} / \mathrm{cm}$ significantly reduced to $14.6 \mathrm{ml} / 100 \mathrm{~g}$ due to the combined effects of $\mathrm{Fe}_{2} \mathrm{O}_{3}$ addition and the slow solidification rate of molten metal. The microstructure also had a significant effect on the corrosion resistance of the weld metal. The weld metal with high proportions of acicular ferrite at low heat input exhibited the lowest corrosion rate, while the base metal possessed a reduced corrosion resistance. These results were helpful to promote the application of low alloy high strength steel in the marine fields.
\end{abstract}

Keywords: Arc stability, Weld quality, Low alloy high-strength steel, Underwater wet welding

\section{INTRODUCTION}

Underwater wet welding, a convenient and low-cost technique, is widely used in the maintenance and repair of underwater steel structures [1]. The direct access of the water to the welding zone results in poor arc stability, a rapid cooling rate and a high diffusible hydrogen content in the deposited metal, which reduces the quality of the wet welded joints [2]. Underwater wet welding is usually divided into underwater shielded metal arc welding (SMAW) and underwater wet self-shielded fluxcored arc welding (FCAW-S). The research on underwater wet SMAW using coated electrodes is well documented $[3,4]$.
With the trend of the developing wet welding process with its advantages of high efficiency and a high degree of automation, the underwater FCAW-S process is receiving more and more attention [5]. Scholars around the world have conducted in-depth research on the stability of the underwater wet FCAW-S process and clearly clarified the characteristics of the bubble and droplet transfer of the underwater wet welding process [6-9]. A series of assisting methods have also been proposed to achieve highquality welded joints, such as ultrasonic [10-11], pulse current [12], pulsed wire feed [13] and temper bead [14].

In order to obtain high-quality underwater wet FCAW-S welded joints, the key is to develop a self-shielded flux-cored wire 
suitable for the wet welding process. However, the development of self-shielded flux-cored wire lags far behind the development of coated electrodes [15-17]. When commercial flux-cored wires were originally tried in underwater surroundings, the quality of the wet welds was poor $[18,19]$. EO Paton Welding Institute carried out work to develop a rutile type of self-shielded flux-cored wire [20]. In spite of the good results achieved, there was little information on this development. Guo studied the underwater wet welding process stability using self-shielded flux-cored wire with the $\mathrm{TiO}_{2}-\mathrm{CaF}_{2}$ slag system [7]. Nevertheless, no detailed information on the slag features was given in the study. Parshin found that the quality of wet welded joints was ensured when selecting the flux-cored wire with the $\mathrm{TiO}_{2}-\mathrm{CaF}_{2}$ slag system [21]. However, the amount of calcium fluoride in the formulation is only $8 \%$. This may not be able to effectively reduce the diffusible hydrogen content in the weld metal. Li designed a self-shielded flux-cored wire with a $\mathrm{CaF}_{2}-\mathrm{Al}_{2} \mathrm{O}_{3}$ slag system, which could be used to join low alloy high strength steel [22]. But this wire had low arc stability under large heat input. In addition, some attempts have been made to acquire high quality wet welds by adjusting the chemical composition of the flux core [23].

To sum up, the self-shielded flux-cored wires designed for underwater wet welding have been mainly based on the $\mathrm{TiO}_{2}-\mathrm{CaF}_{2}$ based system and $\mathrm{CaF}_{2}$ based system. The purpose of adding $\mathrm{CaF}_{2}$ was mainly to decrease the diffusible hydrogen content in the weld metal, but excessive addition will reduce the arc stability and limit its application. Liu pointed out that adding an appropriate amount of $\mathrm{Fe}_{2} \mathrm{O}_{3}$ to the rutile coating could effectively reduce the diffusible hydrogen content on the basis of ensuring the stability of the wet welding process [24]. This method can be applied to the development of underwater wet self-shielded flux-cored wires.

Therefore, the aim of this paper is to explore the feasibility of underwater wet welding of low alloy high strength steel with $\mathrm{TiO}_{2}-\mathrm{Fe}_{2} \mathrm{O}_{3}$ type self-shielded flux-cored wire. The arc stability, microstructure, mechanical properties and corrosion resistance of the wet welded joints were studied. The research in this article helps to promote the development and application of underwater wet self-shielded flux-cored wire welding technology in the marine and shipbuilding fields.

\section{EXPERIMENTAL PROCEDURES}

Underwater wet FCAW-S experiments were carried out at a depth of $0.5 \mathrm{~m}$ in a tank with tap water. The base metal selected in the study was E40 steel with dimensions of $200 \mathrm{~mm} \times 60 \mathrm{~mm} \times 10 \mathrm{~mm}$. The specimen was welded with a $60^{\circ} \mathrm{V}$-groove with a 2-mm root opening, as shown in Fig. 1. The filling material was specially designed self-shielded fluxcored wire with a diameter of $1.6 \mathrm{~mm}$. H08A low carbon steel was selected to form the outside sheath. The mixed powder in tubular wire was composed of $\mathrm{TiO}_{2}, \mathrm{Fe}_{2} \mathrm{O}_{3}, \mathrm{Mn}, \mathrm{Al}, \mathrm{Fe}, \mathrm{LiF}$ and $\mathrm{SiO}_{2}$ in different proportions. $\mathrm{TiO}_{2}$ and $\mathrm{Fe}_{2} \mathrm{O}_{3}$ were the main slag-former, and accounted for more than $50 \%$ of the total mass of the flux. The specific formulation is shown in Table 1 . The chemical composition of the base metal and the weld metal is shown in Table 2 .

The welding power source used for the experiments was the AoTai Pulse MIG-350 with DCEP polarity. The welding process parameters are listed in Table 3. The wire extension was set to $20 \mathrm{~mm}$. A robotic semi-automatic welding system was used to complete the underwater wet welding process. Cooling time from $800^{\circ} \mathrm{C}$ to $500^{\circ} \mathrm{C}\left(\mathrm{t}_{8 / 5}, \mathrm{~s}\right)$ were also calculated using the method suggested by Suga [25], as shown in Eq. (1)- Eq. (3). The calculation results are displayed in Table 3.

$$
\begin{gathered}
H=U^{*} I / V \\
R_{c}=6.25 \times 10^{5} \times U^{-0.95} \times t^{0.17} \\
t_{8 / 5}=455 R_{c}^{-1.09}
\end{gathered}
$$

Where $H$ is heat input $(\mathrm{J} / \mathrm{cm}), U$ is arc voltage $(V), I$ is welding current (A), $V$ is welding speed $(\mathrm{mm} / \mathrm{min}), \mathrm{t}$ is the plate thickness (mm).

Under three different parameters, the arc stability, microstructure and mechanical performance of the welded joints were studied by surface and butt welding processes. Hall sensors and an acquisition card were used to collect and analyse the electrical signals in the underwater wet FCAW-S process.

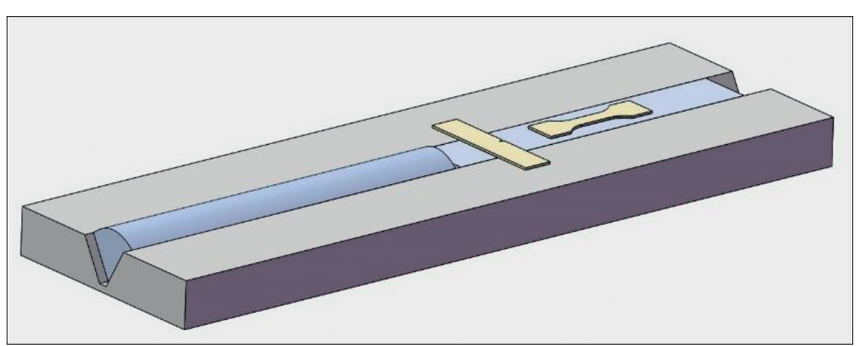

\begin{tabular}{|c|c|c|c|c|c|c|c|c|c|c|c|}
\hline & $\mathrm{TiO}_{2}$ & $\mathrm{Fe}_{2} \mathrm{O}_{3}$ & $\mathrm{SiO}_{2}$ & $\mathrm{Fe}$ & $\mathrm{LiF}$ & Mn & $\mathrm{Ni}$ & $\mathrm{Al}$ & $\mathrm{FeO}$ & $\mathrm{MnO}$ & $\mathrm{Al}_{2} \mathrm{O}_{3}$ \\
\hline Flux formulation & 32 & 20 & 5 & 26 & 5 & 3 & 5 & 4 & - & - & - \\
\hline Slag composition & 35.8 & - & 4.4 & - & - & - & - & - & 34.6 & 14.8 & 8.1 \\
\hline
\end{tabular}

Fig. 1. V-groove design and the extracted positions of mechanical samples

Tab. 1. Flux formulation and slag composition of flux-cored wires (wt.\%)

Tab. 2. Chemical composition of the base metal and the weld metal (wt.\%)

\begin{tabular}{|c|c|c|c|c|c|c|c|}
\hline & $\mathrm{Fe}$ & $\mathrm{C}$ & $\mathrm{Cu}$ & $\mathrm{O}$ & $\mathrm{Mn}$ & $\mathrm{Ni}$ & $\mathrm{Cr}$ \\
\hline E40 steel & Bal. & 0.16 & - & - & 1.36 & 0.05 & 0.02 \\
\hline Weld metal & Bal. & 0.10 & - & 0.094 & 0.41 & 0.8 \\
\hline
\end{tabular}


Tab. 3. Welding parameters

\begin{tabular}{|c|c|c|c|c|}
\hline $\begin{array}{c}\text { Heat } \\
\text { input } \\
(\mathrm{kJ} / \mathrm{cm})\end{array}$ & $\begin{array}{c}\text { Welding } \\
\text { current } \\
(\mathrm{A})\end{array}$ & $\begin{array}{c}\text { Arc } \\
\text { voltage } \\
(\mathrm{V})\end{array}$ & $\begin{array}{c}\text { Travelling } \\
\text { speed } \\
(\mathrm{mm} / \mathrm{min})\end{array}$ & $\begin{array}{c}\Delta \mathrm{t}_{\mathrm{g} / 5} \\
(\mathrm{~s})\end{array}$ \\
\hline 20 & 181 & 25.9 & 140 & 4 \\
\hline 26 & 204 & 27.9 & 130 & 5.2 \\
\hline 32 & 210 & 30.2 & 120 & 6.5 \\
\hline
\end{tabular}

The weld appearances before and after slag removal are illustrated in Fig. 2. It could be seen that there was a layer of black slag on the surface of the weld. The composition of the slag was analysed by X-ray fluorescence spectrometry. The chemical composition of the slag is shown in Table 1. The basicity of the slag was around 1.25. The diffusible hydrogen levels of the weld metal were determined using the glycerine method. Each data point represented an average of six specimens. The specimens for microstructural examination were taken from the thickness section perpendicular to the welding direction. The microstructure of the weld metal etched by $4 \%$ nitric acid solution was characterised by optical microscopy. The impact toughness, tensile strength and corrosion resistance of the weld metal were studied respectively. The data was the average value of at least three samples. The dimensions of the Charpy impact samples and tensile samples are displayed in Fig. 3. The fracture morphologies were observed using a scanning electron microscope.

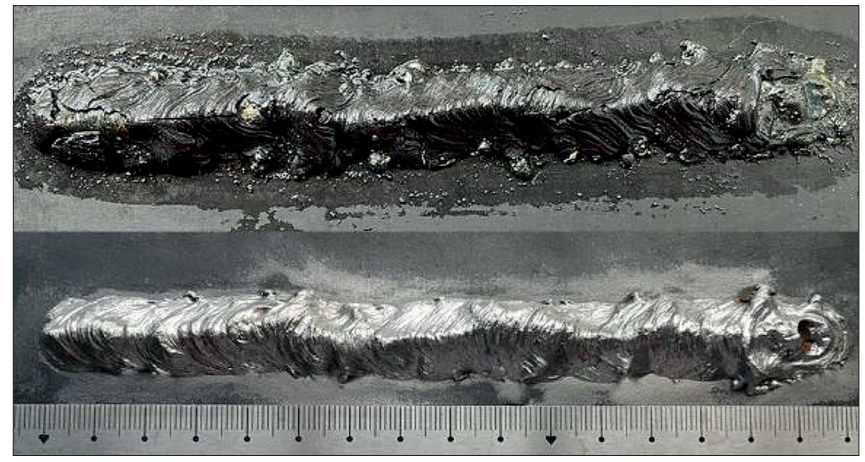

Fig. 2. Surface weld appearance before/after slag removal

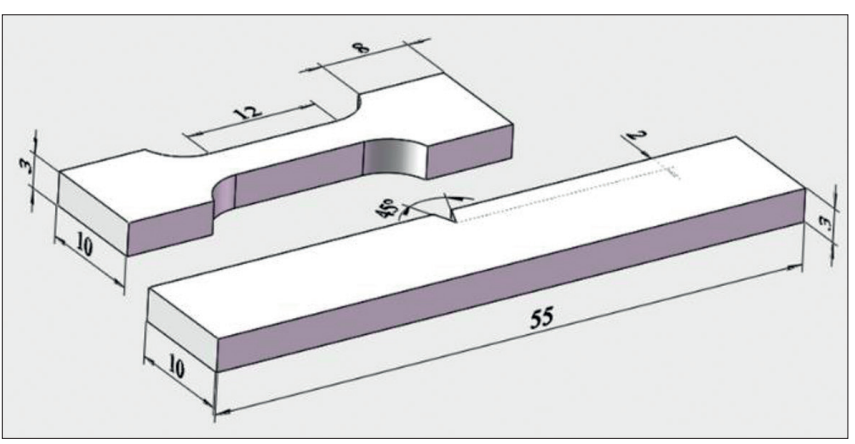

Fig. 3. The dimensions of the Charpy impact samples and tensile samples ( $\mathrm{mm}$ )

The corrosion resistance of the base metal and weld metal was evaluated by potentiodynamic polarisation (PDP) tests. All corrosion tests were conducted in $3.5 \% \mathrm{NaCl}$ solution at room temperature. The tests were carried out in a threeelectrode electrochemical cell system with a saturated calomel electrode as a reference electrode, a platinum mesh as a counter electrode, and welded samples as a working electrode. The specimens were first immersed into $\mathrm{NaCl}$ solution for 15 minutes to achieve the quasi-static open circuit potential. Then, the PDP tests were performed from 0 to 1.2 $\mathrm{V}$ at a scanning rate of $0.01 \mathrm{~V} / \mathrm{s}$. All the electrochemical tests were performed at least three times.

\section{RESULTS AND DISCUSSION}

\section{WELD APPEARANCES AND ARC STABILITY}

The macroscopic weld appearances under three different parameters are presented in Fig. 4 . When the heat input increased from $20 \mathrm{~kJ} / \mathrm{cm}$ to $32 \mathrm{~kJ} / \mathrm{cm}$, all the welds were well formed without surface pores and spatter on either side of the welds. This indicated that the wires developed with $\mathrm{TiO}_{2}-\mathrm{Fe}_{2} \mathrm{O}_{3}$ as the main component of the slag system possessed good operability. As mentioned before, the arc stability for wires with the $\mathrm{CaF}_{2}$ slag system deteriorated at large heat input [22]. Thus, the arc stability of the $\mathrm{TiO}_{2}$ slag system can be maintained in a large range of parameters, which was in keeping with Rowe's findings [3].

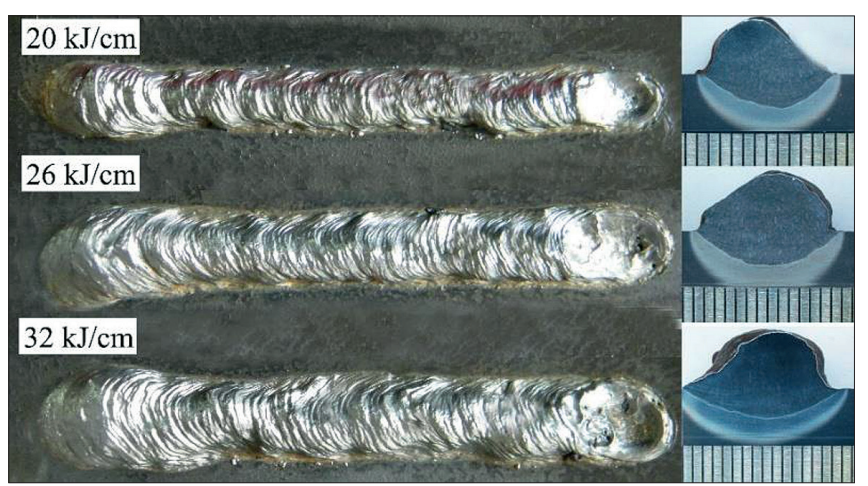

Fig. 4. Bead-on-plate welds and cross-section of welded joints

In order to analyse the arc stability under different welding heat input, the standard deviation, reciprocal coefficient of variation and probability density distribution of arc voltage were selected as evaluation indicators $[7,17,26]$. As shown in Fig. 5(a), the influence of the heat input on the standard deviation and reciprocal coefficient of variation of arc voltage was not obvious. When the heat input was $32 \mathrm{~kJ} / \mathrm{cm}$, the standard deviation of arc voltage increased slightly, indicating that the arc stability deteriorated little. Generally, the arc stability of the developed self-shielded flux-cored wire was maintained at a high level. The results were in accordance with the results of the weld appearances.

According to the influence of the heat input on the arc voltage probability density distribution chart in Fig. 5(b), the arc voltage probability density distribution under each group of heat inputs was very concentrated. After statistical analysis, the proportion of arc voltage in the range of $25-33 \mathrm{~V}$ exceeded $95 \%$ under the three heat inputs. This result further suggested that good welding ability could be obtained for the developed wire. 


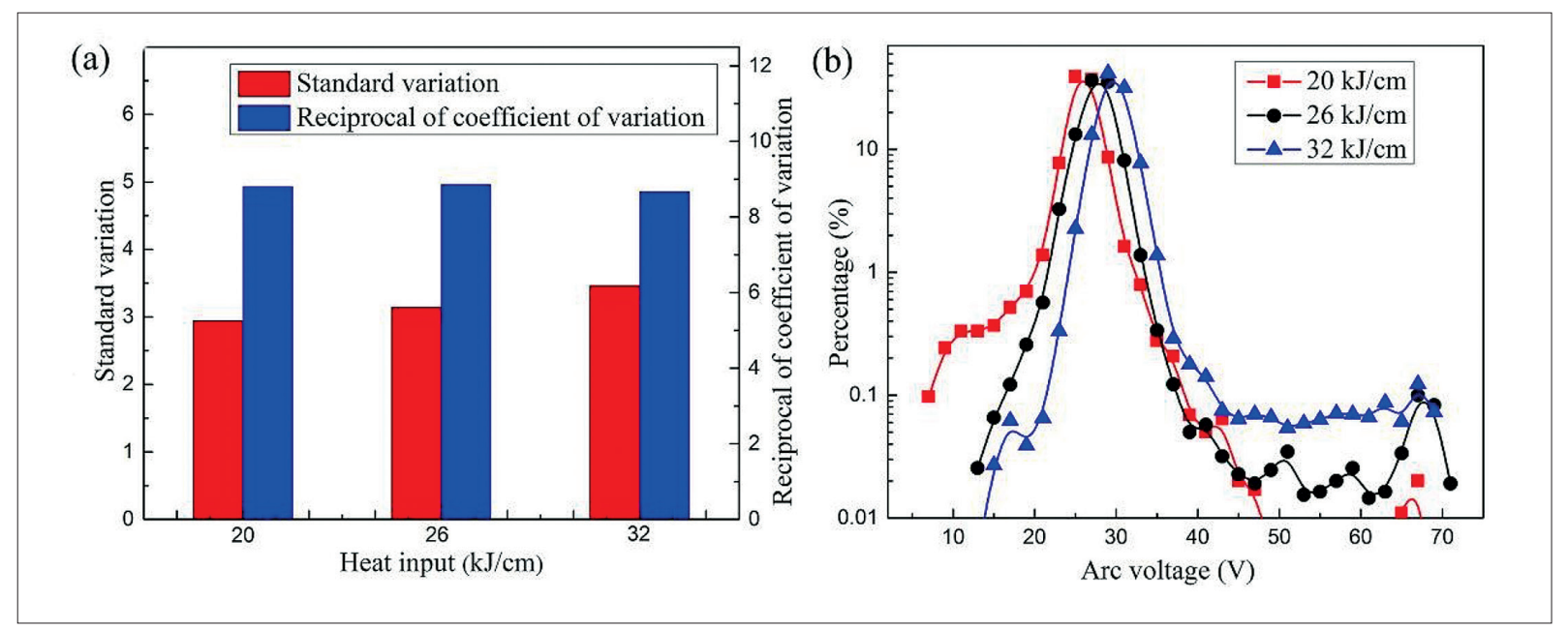

Fig. 5. The change of arc voltage at different heat inputs: (a) Reciprocal of variation coefficient and standard variation of arc voltage, respectively; (b) Probability distribution of arc voltage

To accurately and clearly present the fluctuation of the electrical signal in the entire welding process, a further analysis of the welding current and arc voltage was conducted. Fig. 6 displays voltage/current (U/I) cyclograms for the different heat inputs. An arc extinction region (a voltage threshold $>50 \mathrm{~V}$ ), stable arc burning region and short-circuit region (a voltage threshold $<10 \mathrm{~V}$ ) were observed. The percentage of stable arc burning region followed this sequence: $26 \mathrm{~kJ} / \mathrm{cm}(99.78 \%)$ $>32 \mathrm{~kJ} / \mathrm{cm}(99.65 \%)>28 \mathrm{~kJ} / \mathrm{cm}$ (99.28\%). Compared to flux-core wires with a $\mathrm{CaF}_{2}$-based slag system in the previous study [22], the stable arc burning region became more concentrated and the arc extinction region became less intensified for wires with the $\mathrm{TiO}_{2}$-based slag system. On the whole, the arc stability could be maintained at a high level at the investigated parameters. The above results showed that the process range of low-carbon steel self-shielded flux-cored wire was relatively larger than that of wires with $\mathrm{CaF}_{2}$-based slag system.

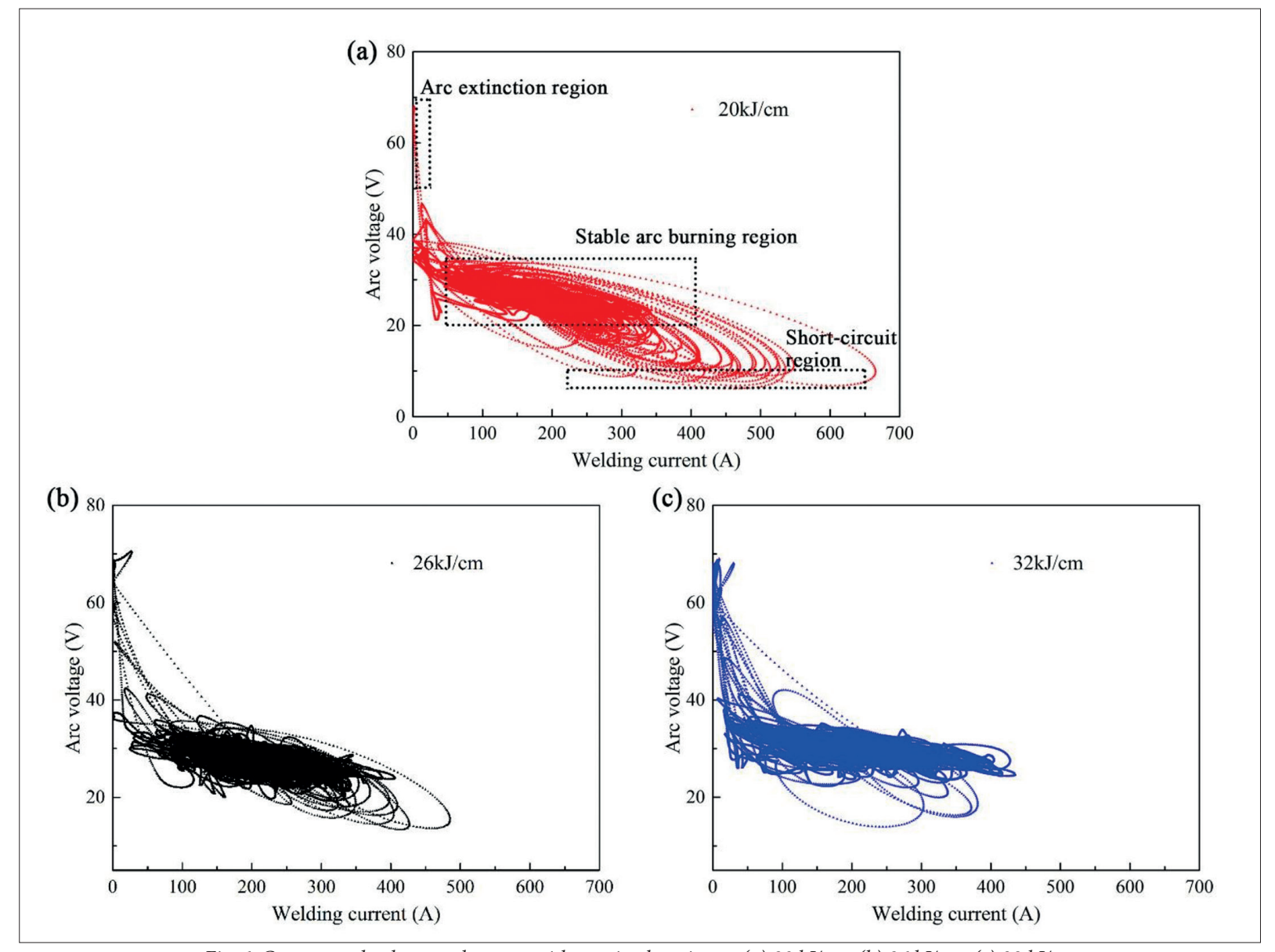

Fig. 6. Current and voltage cyclograms with varying heat input: (a) $20 \mathrm{~kJ} / \mathrm{cm}$, (b) $26 \mathrm{~kJ} / \mathrm{cm}$, (c) $32 \mathrm{~kJ} / \mathrm{cm}$ 

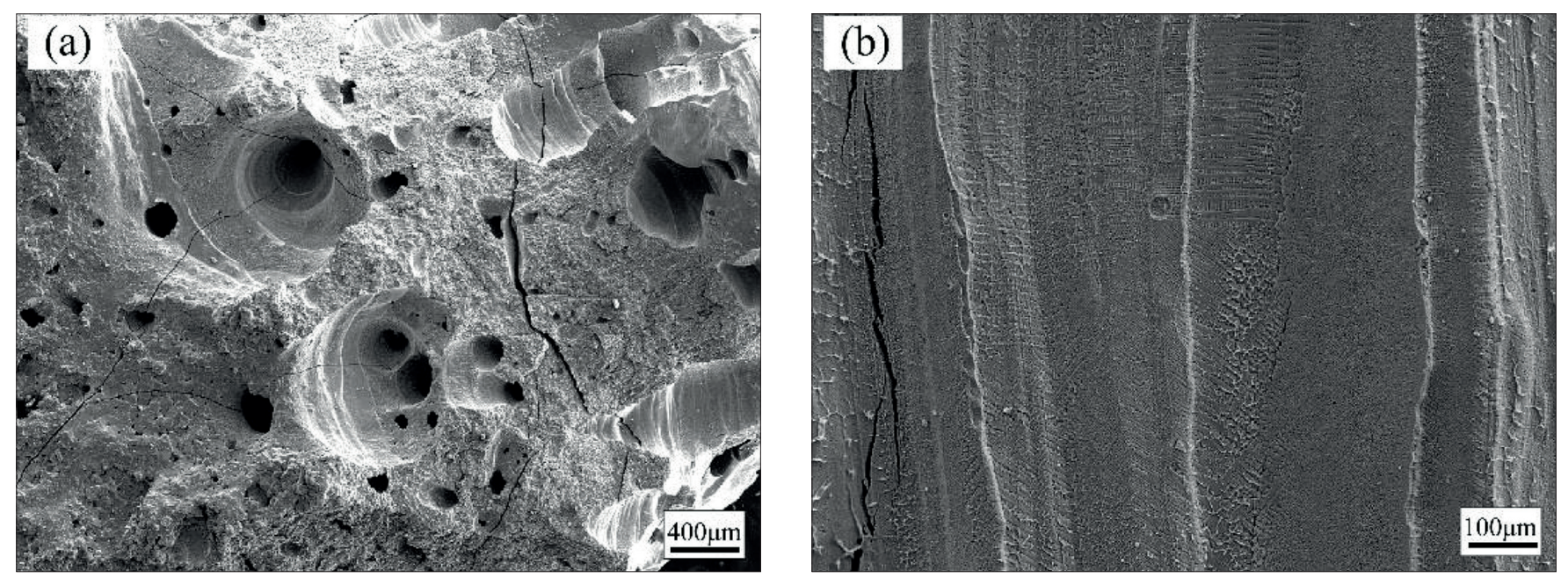

Fig. 7. Microstructural analysis of molten slag: (a) inner surface, (b) outer surface
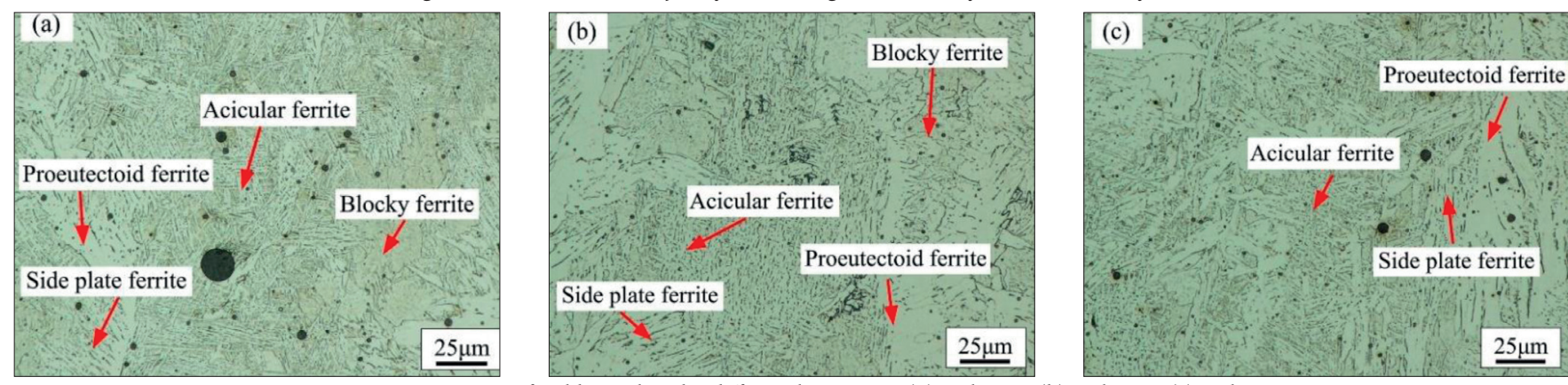

Fig. 8. Microstructure of weld metal under different heat input: (a) $20 \mathrm{~kJ} / \mathrm{cm}$, (b) $26 \mathrm{~kJ} / \mathrm{cm}$, (c) $32 \mathrm{~kJ} / \mathrm{cm}$

Fig. 7 illustrates the microstructure of the inner surface and outer surface of the slag. Combined with the results in Fig. 2, the black slag layer automatically tilted, or was accompanied by transverse cracking after welding. It is expected that the difference of linear expansion coefficients between the weld metal and slag guaranteed slag detachability. In addition, pores were formed in the inner surface of the slag during solidification. This also suggested that a complicated metallurgical reaction occurred in the slag/weld metal interface.

\section{MICROSTRUCTURE AND MECHANICAL PROPERTIES}

Fig. 8 shows the microstructure of the weld metal under different welding heat inputs. When the heat input was $20 \mathrm{~kJ} / \mathrm{cm}$, the microstructure of the weld metal was composed of grain boundary ferrite, side lath ferrite, massive ferrite and acicular ferrite. With the increase of heat input, the proportion of the grain boundary ferrite and side lath ferrite increased, while the proportion of acicular ferrite decreased and coarsened. This was because the large heat input could slow down the cooling rate to a certain extent and increase the amount of high-temperature ferrite in the weld metal. In this case, the amount of acicular ferrite reduced, and the strength and toughness of the weld metal decreased. Fig. 9 illustrates the X-ray detection images of butted welds at a heat input of $32 \mathrm{~kJ} / \mathrm{cm}$. No obvious defects appeared in the weld beam. Therefore, the wet welding quality was guaranteed using the developed $\mathrm{TiO}_{2}-\mathrm{Fe}_{2} \mathrm{O}_{3}$ based flux-cored wire.

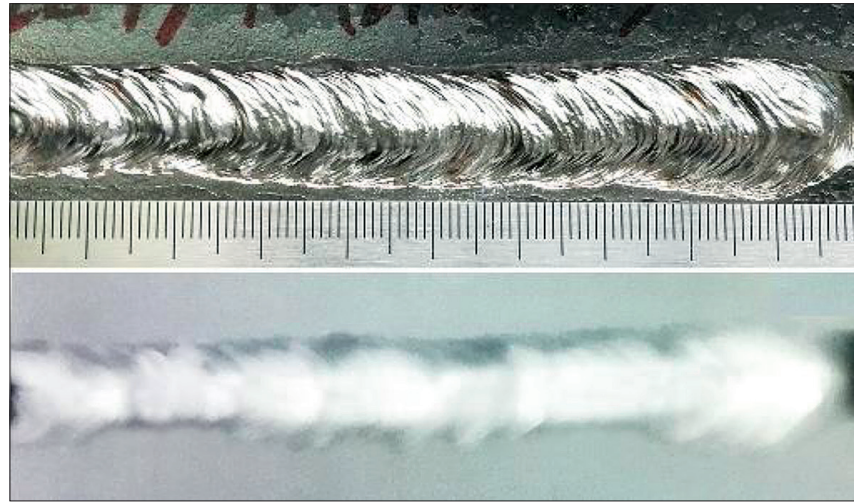

Fig. 9. Wet butted weld appearance and its X-ray detection image at a heat input of $32 \mathrm{~kJ} / \mathrm{cm}$

Under different welding heat inputs, the mechanical properties of the underwater wet welding joints were analysed, as shown in Fig. 10. It could be seen from the figure that, as the heat input increased, the tensile strength and impact toughness of the weld metal decreased to a certain extent, which was consistent with the microstructure analysis results. When the heat input was $20 \mathrm{~kJ} / \mathrm{cm}$, the tensile strength was $520 \mathrm{MPa}$ and the toughness reached $80 \mathrm{~kJ} / \mathrm{cm}^{2}$. Combining the microscopic fracture morphology under different heat inputs shown in Fig. 11, it could be found that the tensile microscopic fractures under the three heat inputs were all composed of a large number of equiaxed dimples, and spherical secondphase inclusions were distributed in the dimples. However, when the heat input increased from $20 \mathrm{~kJ} / \mathrm{cm}$ to $32 \mathrm{~kJ} / \mathrm{cm}$, the dimple diameter became larger and the depth became smaller. 


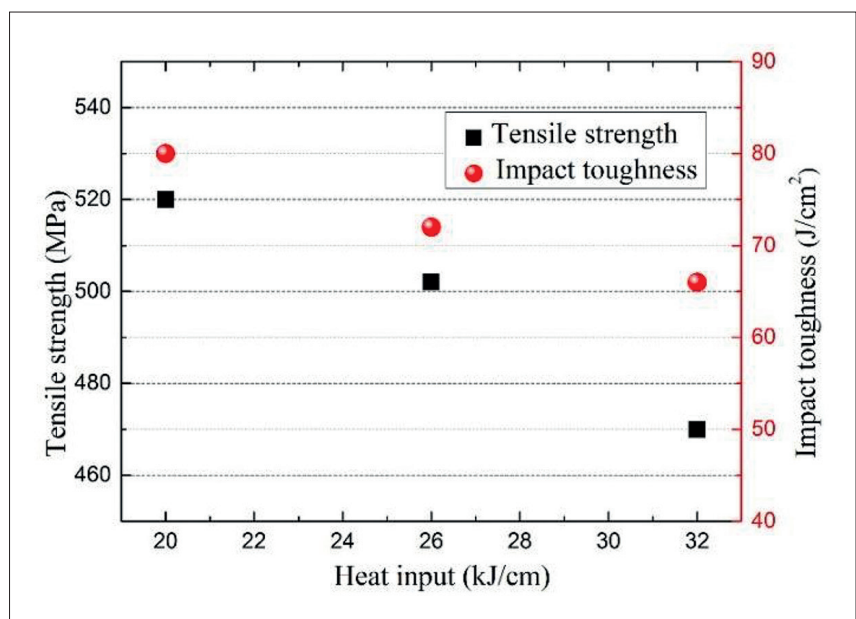

Fig. 10. All-weld-metal tensile strength and Charpy impact toughness at room temperature

When the heat input was $20 \mathrm{~kJ} / \mathrm{cm}$, the diameter of the tensile fracture dimple was $3 \mu \mathrm{m}$ while the dimple diameter was $7 \mu \mathrm{m}$ at $32 \mathrm{~kJ} / \mathrm{cm}$.

A similar phenomenon was observed for the impact fracture morphologies of the weld metal under different heat inputs. Dimples of varying size and shape were observed in all the fractured surfaces, which indicated that the major fracturing mechanism was ductile. From Fig. 11(b), it was clear that the fractured surface of the specimen at low heat input contained a large proportion of small and shallow dimples, which was indicative of its relatively high tensile strength and ductility. From Figs. 11 (d) and (f), as the heat input increased, coarse and elongated dimples were formed.

The weld-metal inclusions were examined using energy dispersive spectrometry (EDS) to determine their chemistry. The inclusion was found to be enriched with $22.6 \mathrm{wt} . \% \mathrm{O}$, 10.7 wt.\%Si, 11.4 wt.\%Mn, and 58.7 wt.\%Fe. It was supposed that the main types of inclusions are $\mathrm{SiO}_{2}, \mathrm{MnO}$ and $\mathrm{FeO}$. The weld-metal inclusions were the primary nucleation sites for acicular ferrite. The major effect of weld-metal inclusions in the nucleation of ferrite was through their ability to reduce the energy barrier to nucleation by acting as an inert substrate, as suggested by Terasaki [27].

\section{CORROSION RESISTANCE}

The curves of weld metal at different heat inputs, and $\mathrm{E} 40$ base metal in $3.5 \% \mathrm{NaCl}$ solution were obtained, as depicted in Fig. 12. The Tafel extrapolation method from the PDP curves was used to determine the corrosion current densities. The corrosion current density and corrosion potentials are summarised in Table 4, where $\mathrm{E}_{\text {corr }}$ represents the corrosion potential and Icorr represents the corrosion current.
It could be observed that the E40 base metal had a more positive potential $(-0.9282 \mathrm{~V})$ and a higher $\mathrm{I}_{\text {corr }}\left(27.5 \mu \mathrm{A} \mathrm{cm} \mathrm{cm}^{-2}\right)$ than that of the weld metal under different heat inputs. This meant that the base metal has a smaller driving force of corrosion and a larger corrosion rate in $\mathrm{NaCl}$ solution. In addition, the $\mathrm{I}_{\text {corr }}$ of the weld metal decreased from $11.6 \mu \mathrm{A} \mathrm{cm}^{-2}$ to $14.2 \mu \mathrm{A} \mathrm{cm} \mathrm{cm}^{-2}$, suggesting that the corrosion resistance deteriorated as the heat input increased. Thus, the corrosion resistance of the weld metal was the best and then came the base metal, which was in accordance with Wang's study [28]. This was attributed to microstructural variation between the base metal and weld metal at different heat inputs.

For weld metal at different heat inputs, the proportions of acicular ferrite could be used to explain the differences in corrosion resistance. On the one hand, a number of dislocations in acicular ferrite may have become the nucleation sites of corrosion cavities, resulting in a great corrosion tendency of acicular ferrite [29]. On the other hand, the lowest corrosion rate of the acicular ferrite could be attributed to the uniform distribution of the phases in the welds [30]. For the base metal, pearlite with the lamellar structure of ferrite and cementite was considered to result from the cooperative growth of both ferrite and cementite. Because the cementite contained in the pearlite was electrochemically more stable than ferrite, the galvanic
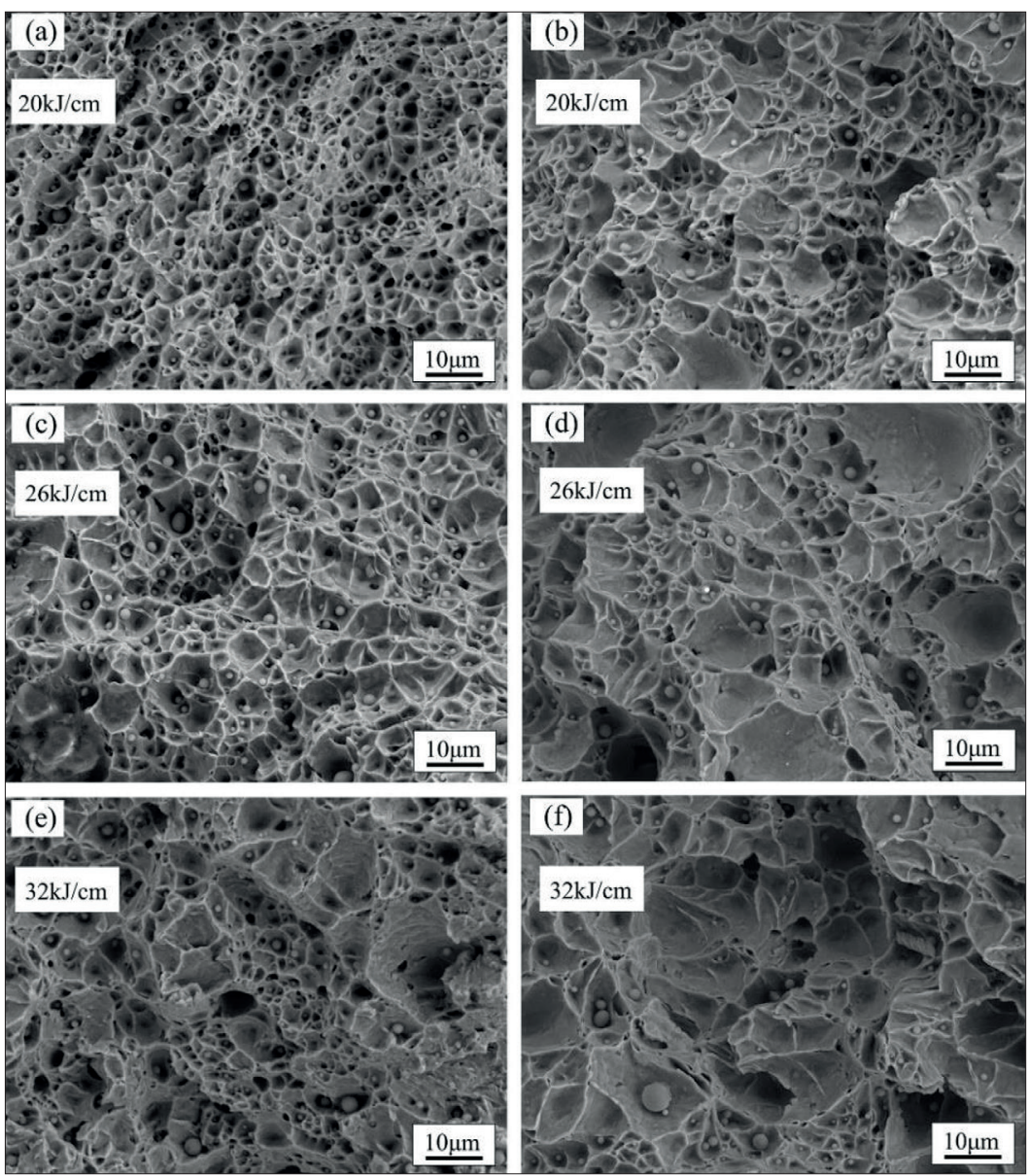

Fig. 11. SEM fractured surfaces of mechanical samples at different heat inputs: (a), (c) and (e) SEM fractographs of tensile specimens at a heat input of $20 \mathrm{~kJ} / \mathrm{cm}, 26 \mathrm{~kJ} / \mathrm{cm}$ and $32 \mathrm{~kJ} / \mathrm{cm}$, respectively; (b), (d) and (f) SEM fractographs of impact toughness test at a heat input of $20 \mathrm{~kJ} / \mathrm{cm}, 26 \mathrm{~kJ} / \mathrm{cm}$ and $32 \mathrm{~kJ} / \mathrm{cm}$ 
effect between the cementite and ferrite would enhance the ferrite corrosion, resulting in a higher corrosion rate, as suggested by Shin [31]. Therefore, the corrosion resistance of the low-alloy steel deteriorated with the presence of pearlite.

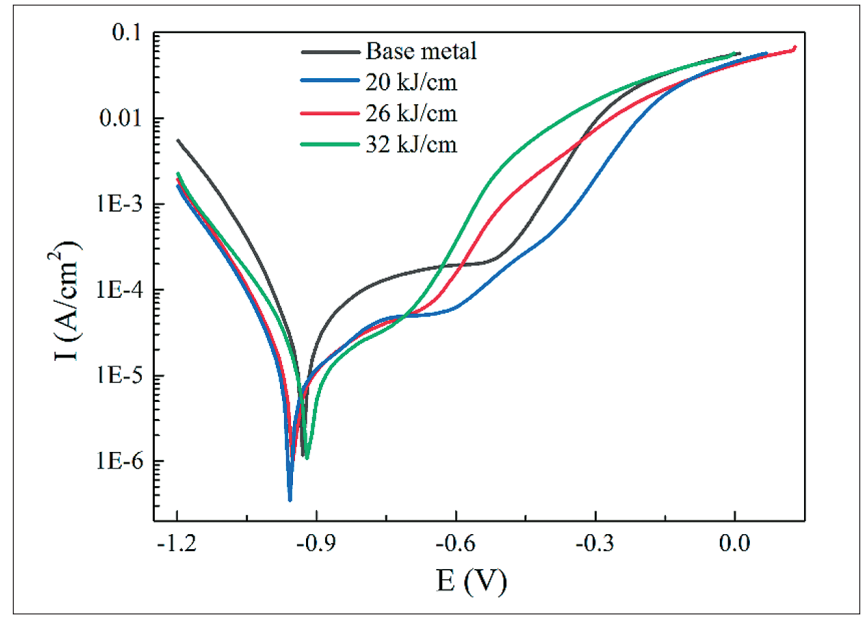

Fig. 12. Polarisation curve of base metal and weld metal under different heat inputs

Tab. 4. Electrochemical parameters obtained from potentiodynamic curves

\begin{tabular}{|c|c|c|c|c|}
\hline & $\begin{array}{c}\text { Base } \\
\text { metal }\end{array}$ & $20 \mathrm{~kJ} / \mathrm{cm}$ & $26 \mathrm{~kJ} / \mathrm{cm}$ & $32 \mathrm{~kJ} / \mathrm{cm}$ \\
\hline $\mathrm{E}_{\text {corr }} / \mathrm{V}$ & -0.9282 & -0.9488 & -0.9565 & -0.9173 \\
\hline $\mathrm{I}_{\text {corr }} / \mathrm{A} \cdot \mathrm{cm}-2$ & $2.75 \mathrm{E}-5$ & $1.16 \mathrm{E}-5$ & $1.23 \mathrm{E}-5$ & $1.42 \mathrm{E}-5$ \\
\hline
\end{tabular}

\section{ADVANTAGES OF OXYRUTILE FLUX-CORED WIRE}

Haematite $\left(\mathrm{Fe}_{2} \mathrm{O}_{3}\right)$ was introduced into $\mathrm{TiO}_{2}-\mathrm{SiO}_{2}$ based flux-cored wire to form $\mathrm{TiO}_{2}-\mathrm{Fe}_{2} \mathrm{O}_{3}$ flux-cored wire. The main aim was to develop a self-shielded flux-cored wire based on iron oxide and titanium oxide with improved mechanical properties, low diffusible hydrogen content and good operability.

Firstly, statistical analysis of the electrical signals suggested that the developed flux-cored wires produced a stable arc and regular bead appearance under the range of investigated parameters. This meant that good operability could be achieved for the flux-cored wire. After welding, a layer of black slag was uniformly deposited on the surface of the welds, which could effectively protect the weld metal. According to Table 1, the slag system of the wire was $\mathrm{TiO}_{2}-\mathrm{FeO}-\mathrm{MnO}$ and the slag basicity was about 1.25 . On the one hand, a more basic flux was expected to reduce the weld metal hydrogen content. The introduction of $\mathrm{Fe}_{2} \mathrm{O}_{3}$ to the flux formulation led to an increase in the flux basicity and oxygen concentration, which helped to decrease the diffusible hydrogen content. In addition, the decrease in the weld metal hydrogen content with an increase in the level of oxidising ingredients in the flux can also be ascribed to the formation of a monolayer of $\mathrm{FeO}$ at the slag/metal interface, which prevented hydrogen adsorption [32]. The mechanism could be described as follows:

As shown in Eq. (4), $\mathrm{Fe}_{2} \mathrm{O}_{3}$ in flux-cored wire would decompose to form $\mathrm{FeO}$ in the arc and weld pool. Then, $\mathrm{FeO}$ reacted with hydrogen, as illustrated by the reaction shown in Eq. (5). This reduces the hydrogen content in deposited weld metal. Meanwhile, the partial pressure of hydrogen in the arc is reduced due to dilution of the oxygen produced by the dissociation of $\mathrm{Fe}_{2} \mathrm{O}_{3}$. It is known that the increase in the oxygen content of the weld metal drives reaction (Eq. (6)) to the left, thereby decreasing the hydrogen content [33].

$$
\begin{gathered}
2 \mathrm{Fe}_{2} \mathrm{O}_{3} \rightarrow 4 \mathrm{FeO}+\mathrm{O}_{2} \\
\mathrm{FeO}+2 \mathrm{H} \rightarrow \mathrm{Fe}+\mathrm{H}_{2} \mathrm{O} \\
\mathrm{H}_{2} \mathrm{O} \leftrightarrow 2 \mathrm{H}+\mathrm{O}
\end{gathered}
$$

This fact could be verified by the diffusible hydrogen content of the weld metal at the different heat inputs in Table 5. The addition of $\mathrm{Fe}_{2} \mathrm{O}_{3}$ into the flux could reduce the hydrogen content to below $20 \mathrm{ml} / 100 \mathrm{~g}$. Therefore, a low diffusible hydrogen content is helpful to mitigate the tendency of hydrogen-induced cracking [34].

Tab. 5. Diffusible hydrogen content at different parameters

\begin{tabular}{|c|c|c|c|}
\hline Heat input $(\mathrm{kJ} / \mathrm{cm})$ & 20 & 26 & 32 \\
\hline Hydrogen content $(\mathrm{ml} / 100 \mathrm{~g})$ & 20.8 & 14.6 & 16.3 \\
\hline
\end{tabular}

It should be noted that the addition of $\mathrm{Fe}_{2} \mathrm{O}_{3}$ would increase the oxygen content of the weld metal, which may influence the impact toughness of the weld metal. The results showed that the weld metal contained a high level of oxygen $(0.125 \mathrm{wt} . \%)$. In order to improve the mechanical performance of their deposits, $\mathrm{Mn}$ and Ni were selected as the main alloying elements that transferred to the weld metal, as demonstrated in Table 2. This conclusion could be verified by the superior mechanical properties in Fig. 7. Pope also pointed out that acceptable properties can be obtained for a high-oxygen underwater wet welds when an optimum nickel content was used [35].

It was recognised that underwater dry welding required a hyperbaric chamber with large support equipment. The estimated cost and time for dry welded repairs are twice those for wet welded repairs [36, 37]. Therefore, the underwater wet welding process in the present study is more versatile and cost-effective than that of underwater dry welding. This is very important for urgent repairs of ships and offshore platforms. Also, the formulation of flux-cored wires could be adjusted according to the practical applications. Among the studies of low carbon steel self-shielded flux-cored wire of underwater wet welding around the world, the mechanical performances of the weld metal reached the international advanced level.

\section{CONCLUSIONS}

The following conclusions could be drawn from the present work:

(1) For the three sets of heat input, the underwater wet welding arc stability was maintained at a high level, and the weld 
appearance was uniform, without surface porosity and spatters. This indicated that the developed wires with $\mathrm{TiO}_{2}-\mathrm{FeO}-\mathrm{MnO}$ displayed good operability in a large range of parameters.

(2) The microstructure and mechanical properties of the weld metal were strongly affected by the heat input. The quantity of the grain boundary ferrite and side lath ferrite increased, thus the mechanical properties of the weld deteriorated as a result of the high heat input.

(3) The microstructure also had a significant effect on the corrosion resistance of the weld metal. The corrosion resistance of the weld metal under three kinds of heat input was superior to that of the base metal, but it decreased with the rise of the heat input.

(4) In terms of the arc stability, mechanical properties and corrosion resistance, a sound weld could be achieved using the developed self-shielded tubular wire with $\mathrm{TiO}_{2}-\mathrm{FeO}-\mathrm{MnO}$ slag system at a heat input of $20 \mathrm{~kJ} / \mathrm{mm}$.

\section{ACKNOWLEDGEMENTS}

We are grateful for the financial support to this research from the National Natural Science Foundation of China (Grant No. 51905225) and the Postgraduate Research \& Practice Innovation Program of Jiangsu Province (Grant No. SJCX20_1400).

\section{REFERENCES}

1. G. Rogalski, D. Fydrych, and J. Łabanowski, "Underwater wet repair welding of API 5 L X65M pipeline steel", Polish Maritime Research, special issue S1 (93), vol. 24, pp. 188-194, 2017, doi: 10.1515/pomr-2017-0038.

2. D. Fydrych, J. Łabanowski, and G. Rogalski, "Weldability of high strength steels in wet welding conditions", Polish Maritime Research, vol. 20, no. 2, pp. 67-73, 2013, doi: 10.2478/ pomr-2013-0018.

3. M. Rowe and S. Liu, "Recent developments in underwater wet welding", Science and Technology of Welding and Joining, vol. 6, no. 6, pp. 387-396, 2001, doi: 10.1179/stw.2001.6.6.387.

4. S. Y. Maksimov, "Development of MMA electrodes for manual underwater welding in all spatial positions of steels", In: International seminar and workshop on underwater wet welding and cutting, Middlesbrough, UK, April 17-18, 1997, pp. 32-44, doi: 10.1533/9780857093165.30.

5. L. O. Vilarinho, B. Lucas and S. Raghunathan, "Initial trials of underwater wet welding using mechanised FCAW process", In: Proceedings of the 20th International Congress of Mechanical Engineering, Gramado, RS, Brazil November 15-20, 2009, pp.15-20. Available: https://www.abcm.org.br/ anais/cobem/2009/pdf/COB09-0213.

6. H. Chen, N. Guo, L. Huang, J. C. Feng, and G. D. Wang,
"Effects of arc bubble behaviors and characteristics on droplet transfer in underwater wet welding using in-situ imaging method", Materials \& Design, vol. 170, p. 107696. 2019, doi: 10.1016/j.matdes.2019.107696

7. Y. L. Fu, N. Guo, Y. P. Du, H. Chen, C. S. Xu, and J. C. Feng, "Effect of metal transfer mode on spatter and arc stability in underwater flux-cored wire wet welding", Journal of Manufacturing Processes, vol. 35, pp. 161-168, 2018, 10.1016/j.jmapro.2018.07.027.

8. J. F. Wang, Q. J. Sun, S. Zhang, C. J. Wang, and J. C. Feng, "Characterization of the underwater welding arc bubble through a visual sensing method", Journal of Materials Processing Technology, vol. 251, pp. 95-108, 2018, doi: 10.1016/j.jmatprotec.2017.08.019.

9. C. B. Jia, Y. Zhang, B. Zhao, J. K. Hu, and C.S. Wu, "Visual sensing of the physical process during underwater wet FCAW", Welding Journal, vol. 95, no. 6, pp. 202-209, 2016, doi: $10.29391 / 2016.99 .006$

10. H. Chen, N. Guo, K. X. Xu, C. Liu, and G.D. Wang, "Investigating the advantages of ultrasonic-assisted welding technique applied in underwater wet welding by in-situ X-ray imaging method", Materials, vol. 13, no. 6, pp. 1442, 2020, doi: 10.3390/ma13061442.

11. J. F. Wang, Q. J. Sun, L. J. Wu, Y. B. Liu, J. B. Teng, and J. C. Feng, "Effect of ultrasonic vibration on microstructural evolution and mechanical properties of underwater wet welding joint", Journal of Materials Processing Technology, vol. 246, pp. 185-197, 2017, doi: 10.1016/j.jmatprotec.2017.03.019.

12. C. B. Jia, J. Wu, Y. F. Han, Y. Zhang, Q. Y. Yang, and C. S. Wu, "Underwater Pulse-Current FCAW-Part 1: Waveform and Process Features", Welding Journal, vol. 99, no. 5, pp.135-145, 2020, doi: 10.29391/2020.99.005

13. N. Guo, Y. P. Du, S. Maksimov, J. C. Feng, and Z. Q. Yin, "Study of metal transfer control in underwater wet FCAW using pulsed wire feed method", Welding in the World, vol. 62, no. 1, pp. 87-94, 2018, doi: 10.1007/s40194-017-0497-y.

14. D. Fydrych, A. Świerczyńska, G. Rogalski, J. Łabanowski, "Temper bead welding of S420G2+M steel in water environment", Advances in Materials Science, vol. 16, no. 4, pp. 5-14, 2016, doi: 10.1515/adms-2016-0018.

15. E. C. P. Pessoa and S. Liu, "The State of the Art of Underwater Wet Welding Practice: Part 2", Welding Journal, vol. 100, pp. 171-182, 2021, doi: 10.29391/2021.100.014

16. E. C. Amaral, A. M. Moreno-Uribe, and A. Q. Bracarense, "Effects of PTFE on operational characteristics and diffusible $H$ and $O$ contents of weld metal in underwater wet welding", Journal of Manufacturing Processes, vol. 61, pp. 270-279, 
2021, doi: 10.1016/j.jmapro.2020.11.018

17. H. L. Li, D. Liu, Y. T. Yan, N. Guo, and J. C. Feng, "Microstructural characteristics and mechanical properties of underwater wet flux-cored wire welded 316 L stainless steel joints", Journal of Materials Processing Technology, vol. 238, pp. 423-430, 2016, doi: 10.1016/j.jmatprotec.2016.08.001.

18. A. M. Brydon, and J. H. Nixon, "An investigation into underwater wet welding using the flux cored arc welding process", In: International conference on offshore mechanics and arctic engineering, Copenhagen (Denmark), June 18-22, 1995, available: https://www.osti.gov/biblio/205448

19. H. L. Li, D. Liu, Y. Y. Song, Y. T. Yan, N. Guo, and J. C. Feng, "Microstructure and mechanical properties of underwater wet welded high-carbon-equivalent steel Q460 using austenitic consumables", Journal of Materials Processing Technology, vol. 249, pp. 149-157, 2017, doi: 10.1016/j. jmatprotec.2017.06.009.

20. V. Y Kononenko, "Mechanised welding with self-shielding, flux-cored wires for repairing hydraulic installations and vessels in water", Welding International, vol. 10, no. 12, pp. 994-997, 1996, doi: 10.1080/09507119609549127.

21. S. G Parshin, "Underwater wet FCA-welding of highstrength steel X70 through the use of flux-cored electrode", Welding International, vol. 34, no. 1, pp. 24-28, 2020, doi: 10.1080/09507116.2021.1918470

22. H. L. Li, D. Liu, Y. T. Yan, N. Guo, Y. B. Liu, and J. C. Feng, "Effects of heat input on arc stability and weld quality in underwater wet flux-cored arc welding of E40 steel', Journal of Manufacturing Processes, vol. 31, pp. 833-843, 2018, doi: 10.1016/j.jmapro.2018.01.013

23. X. Zhang, N. Guo, C. S. Xu, Y. P. Du, B. Chen, and J. C. Feng, "Influence of CaF2 on microstructural characteristics and mechanical properties of 304 stainless steel underwater wet welding using flux-cored wire", Journal of Manufacturing Processes, vol. 45, pp. 138-146, 2019, doi: 10.1016/j. jmapro.2019.07.003

24. V. R. Santos, M. J. Monteiro, F. C. Rizzo, A. Q. Bracarense, E. C. P. Pessoa, and L. A. Vieira, "Development of an oxyrutile electrode for wet welding". Welding Journal, vol. 91, no. 12, pp. 319-328, 2012, doi: 10.29391/2012.91.012

25. Y. Suga, "The Effect of Cooling Rate on Mechanical Properties of Underwater Wet Welds in Gravity Arc Welding", Transaction of the Japan Welding Society, vol. 21, pp. 144-149, 1990, available: https://dl.ndl.go.jp/info:ndljp/pid/10945694

26. E. C. P. Pessoa, L. F. Ribeiro, and A. Q. Bracarense, "Arc stability indexes evaluation on underwater wet welding”, In: ASME 2010 29th International Conference on Offshore
Mechanics and Arctic Engineering, Shanghai, China, June 6-11, 2010, pp. 195-201. doi: 10.1115/OMAE2010-20876

27. H. Terasaki and Y. Komizo, "In-situ observation of morphological development for acicular ferrite in weld metal", Science and Technology of Welding and Joining, vol. 11, no. 5, pp.561-566, 2006, doi: 10.1179/174329306X149795.

28. J. F. Wang, J. K. Ma, Y. B. Liu, T. Zhang, S.C. Wu, and Q. J. Sun, "Influence of Heat Input on Microstructure and Corrosion Resistance of Underwater Wet-Welded E40 Steel Joints", Journal of Materials Engineering and Performance, vol. 29, no. 11, pp. 6987-6996, 2020, doi: 10.1007/s11665-020-05160-7

29. R. A. Ricks, P. R. Howell, and G. S. Barritte, "The nature of acicular ferrite in HSLA steel weld metals", Journal of Materials Science, vol. 17, no. 3, pp. 732-740, 1982, doi: 10.1007/BF00540369

30. Y. B. Guo, C. Li, Y. C. Liu, L. M. Yu, Z. Q. Ma and H. J. $\mathrm{Li}$, "Effect of microstructure variation on the corrosion behavior of high-strength low-alloy steel in $3.5 \mathrm{wt} \% \mathrm{NaCl}$ solution", International Journal of Minerals, Metallurgy, and Materials, vol. 22, no. 6, pp. 604-612, 2015, doi: 10.1007/ s12613-015-1113-z.

31. S. Y. Shin, B. Hwang, S. Lee, and N. Kim, "Correlation of microstructure and Charpy impact properties in API X70 and X80 line-pipe steels", Materials Science and Engineering: A, vol. 458, no.1, pp. 281-289, 2007, doi: 10.1016/j. msea.2006.12.097.

32. R. C. De Medeiros and S. Liu, "A predictive electrochemical model for weld metal hydrogen pickup in underwater wet welds", Journal of Offshore Mechanics and Arctic Engineering, vol. 120, no. 4, pp. 243-248, 1998, doi: 10.1115/1.2829547

33. J. Du Plessis and M. Du Toit, "Reducing diffusible hydrogen contents of shielded metal arc welds through addition of fluxoxidizing ingredients", Journal of Materials Engineering and Performance, vol. 17, no. 1, pp. 50-56. 2008, doi: $10.1115 / 1.2829547$

34. J. Tomków, J. Łabanowski, and D. Fydrych, "Cold cracking of S460N steel welded in water environment", Polish Maritime Research, vol. 25, no. 3, pp. 131-136, 2018, doi: 10.2478/ pomr-2018-0104

35. J. Łabanowski, D. Fydrych, G. Rogalski, "Underwater Welding-a review", Advances in materials Science, vol. 8 no.3, pp. 11-22, 2008, doi: 10.2478/v10077-008-0040-3

36. K. Sun, Y. Hu, Y. Shi, and B. Liao, "Microstructure Evolution and Mechanical Properties of Underwater Dry Welded Metal of High Strength Steel Q690E under Different Water Depths", Polish Maritime Research, vol. 27, no. 4, 2020, doi: 10.2478/ pomr-2020-0071. 


\section{CONTACT WITH THE AUTHORS}

Hongliang Li

e-mail: lihongliang23@163.com

Jiangsu University

301 Xuefu Road, Zhenjiang, Jiangsu Province

212013 ZhenJiang

Harbin Institute of Technology

92 Xi Da Zhi Jie, Nangang Qu, Harbin

150001 Harbin

China

Shixiong Liu

e-mail: liushixiong0612@163.com

Jiangsu University

301 Xuefu Road, Zhenjiang, Jiangsu Province

212013 ZhenJiang

China

\section{Qiang Ma}

e-mail: maqiang_2020@163.com

Jiangsu University

301 Xuefu Road, Zhenjiang, Jiangsu Province

212013 ZhenJiang

China

\section{Pengfei Wang}

e-mail:wpf83387973@gmail.com

Peter the Great St. Petersburg Polytechnic University

St. Petersburg, Polytechnicheskaya, 29

195251 St. Petersburg

\section{Russia}

Duo Liu

e-mail: liuduo0376@163.com

Harbin Institute of Technology

92 Xi Da Zhi Jie, Nangang Qu, Harbin

150001 Harbin

China

$$
\begin{gathered}
\text { Qiang Zhu } \\
\text { e-mail: zhuqiang@ujs.edu.cn } \\
\text { Jiangsu University }
\end{gathered}
$$

301 Xuefu Road, Zhenjiang, Jiangsu Province

212013 ZhenJiang

\section{China}

